\title{
PRIMARY ENGLISH TEACHERS PROFESSIONAL DEVELOPMENT DURING COVID19 PANDEMIC: A PRELIMINARY RESEARCH
}

\author{
Wiputra Cendana ${ }^{1}$, Yonathan Winardi ${ }^{2}$ \\ ${ }^{1}$ Universitas Pelita Harapan \\ Email: wiputra.cendana@uph.edu \\ ${ }^{2}$ Universitas Pelita Harapan \\ Email: yonathan.winardi@uph.edu
}

\begin{abstract}
There have been many ways offered as professional development (PD) for language teachers as well as conferences discussing its trends and alternatives. However, the world is facing CoVid19 pandemic that changes the context and media of English language teaching and learning in primary classrooms at present. Therefore, there is a need for novice teachers to be equipped by ways and opportunities in professional development that suit with the existing context and available media to apply PD. A preliminary cross-sectional survey was done in late July 2020 to get feedback on the ways primary English teachers of two private schools in West Jakarta did professional development. Possible solutions and opportunities are offered to assist them having a sustainable and meaningful professional development in the future during home-based learning (HBL) due to CoVid19 pandemic. The conclusion of the research is the primary English teachers have done various PD ways such as joining workshops and conferences, having team teaching, and also developing handouts or modules, yet they need internal and external support from the school and local government mainly in the infrastructure, in order to provide the best possibility of the new learning experience with the students in the online classroom.
\end{abstract}

Keywords: CoVid19 pandemic, primary English teachers, professional development (PD).

\begin{abstract}
Abstrak
Ada banyak cara yang ditawarkan sebagai pengembangan profesional (PD) untuk guru bahasa serta konferensi yang membahas tren dan alternatifnya. Namun, dunia sedang menghadapi pandemi CoVid19 yang mengubah konteks dan media pembelajaran bahasa Inggris di kelas dasar saat ini. Oleh karena itu, guru baru perlu dibekali dengan cara dan peluang pengembangan keprofesian yang sesuai dengan konteks yang ada dan media yang tersedia untuk mengaplikasikan PD. Survei awal cross-sectional dilakukan pada akhir Juli 2020 untuk mendapatkan masukan tentang cara guru bahasa Inggris di dua sekolah swasta di Jakarta Barat melakukan pengembangan profesional. Solusi dan peluang yang mungkin ditawarkan untuk membantu mereka memiliki pengembangan profesional yang berkelanjutan dan bermakna di masa depan selama pembelajaran berbasis di rumah (HBL) karena pandemi CoVid19. Kesimpulan dari penelitian ini adalah guru bahasa Inggris sekolah dasar telah melakukan berbagai cara PD seperti mengikuti pelatihan dan konferensi, melakukan mengajar tim, dan mengembangkan modul, tetapi tetap membutuhkan dukungan internal dan eksternal dari pihak sekolah dan pemerintah daerah terutama di bidang infrastruktur, guna memberikan kemungkinan terbaik pengalaman belajar baru dengan siswa secara online.
\end{abstract}

Kata kunci: Pandemi CoVid19, guru bahasa Inggris sekolah dasar, pengembangan profesional (PD) 


\section{Introduction}

Covid19 pandemic is inevitable, yet has made primay teachers be more creative, collaborative and studentcentered as schools are applying homebased learning (HBL) using various online learning platforms such as Ms.Teams, Edmodo, Google classroom, and Moodle. It has been more than five months and no one knows when this pandemic stops. As the new academic school year has started, some schools also choose Zoom as an online platform for it is easier, lighter, and cheaper. It is a fact that online learning practice at the moment is still far from an ideal setting and system. Internal and external problems exist and should not be considered trivial. The rights of children and youth for proper education and health need to be fulfilled by the government. The government must create educational policies and programs that are really effective yet comprehensive.

It has been such a challenging experience when primary English teachers are doing an online learning with synchronous and asynchronous teaching experience. Reflecting back from the third quarter in the past academic year, there were some of miscommunications happened as well in the learning processes. The obstacle could raise from the way people communicate through written ways or the technical problem like poor internet connection. The teachers are struggling to make the boundaries in their online classroom teaching as well as in using the technology as the new way of communication with the primary students. The internet addiction and an addiction with the gadget for long time period is also another issue taking place in the learning experience.

The relationship in the school ecosystem is a quite challenging part as well. Direct communication still holds a significant role thus far rather than indirect communication. For schools in the green category and they already conduct face to face classes, by having the physical distancing, it impacts the way of communication too. The schools need to have a clarity and intentionality to make a good connection of communication among the primary students, parents, and teachers. Sometimes, the oral communication holds much better to make people understand rather than written communication. Human as the relational being can express their emotion and feeling when they are doing direct communication.

Out of those many areas in primary education to be researched, this time the research focuses on the teachers, especially their PD. Their PD can really help them and the students, even the parents in the future/long term. Therefore, this survey research has three research questions as follow

1. What type of professional development (PD) do primary English teachers apply at the moment? face?

2. What are the challenges they

3. What do they expect from the school and local government?

The aims of this paper are to know the type of PD that English primary English teachers apply at present, to 
know the challenges and to offer visible solutions, and to know opportunities when the school and local government assist them in PD. This paper will be also beneficial for the decision makers in schools to produce a more effective PD or to continue good PD that has been implemented.

English language teaching and learning is actually unique for some characteristics such as small class is preferred, authenticity is crucial, abundant feedback is expected, and affective filter factor needs to be considered. English primary teachers need to demonstrate high English proficiency, consistent foreign language pedagogy, and authentic assessments in order to teach English effectively, not to teach about English. Teaching English and teaching about English are two different things.

Richards (2005) elaborated common ways of PD done by language teachers are joining workshops/conferences, keeping a teaching journal/reflections and portfolios as ways of self monitoring, doing action research, having peer observations and coaching, holding teacher support groups, taking further study, and applying team teaching. It is also believed that developing English module/handouts is another way for teachers to develop profesionally as it gives them a chance to be reflective, relevant, and responsible. The students might not be able to get printed textbooks at the moment due to the pandemic and travel ban/limitation, so teachers' digital material or module is expected. The module and handouts may cover assessments and rubrics in in.
In addition, an ELT expert, Richards (2005) recommended two scopes of teacher's training which are training and development. Training refers to activities directly focused on a teacher's present responsibilities. Development referes to general growth of teachers'understanding of teaching and of themselves as teachers. Harmer (2001a) shared some strategies to teach English with the acronym PPP which stands for Presentation, Practice, Production. Those words relate with how the English teacher could use any concrete material/visual media to present the English lesson. Then, let the students do group/self-practice. Finally, they can present it into the production process. This approach raised the students' level of English skills improvement. Furthermore, Harmer (2001b) recommended that the English teacher make a balance for Teacher Talking Time (TTT) and Student Talking Time (STT). Giving the room for STT is the best scenario to raise the student's level of speaking skill improvement. They will not be afraid to share their opinion with English language as the second language. Keep appreciating the students who tried their best to use the vocabulary that they had to articulate the ideas.

In addition to possible training content mentioned by Harmer, Brown and Abeywicrama (2004) encourage the English teacher to implement informal assessment by starting the incidental, unplanned comments and responses, along with coaching and other impromptu feedback on the student such as 'nice job', 'good work', 'I think you meant to say you broke the glass, not you break 
the glass' or putting a smiley face on some works. These kinds of respond will create a room of encouragement and positive culture in the classroom that the English teacher can create. So then, there will be a relationship during the process of assessment.

Another form of PD is the existence of TSG. Teacher Support Group (TSG) was designed to provide opportunites for teachers to validate both teacher knowledge and teacher inquiry (Hargreaves et al., 1998). MGMP has been quite popular as a form of TSG in local provinces or districts in Indonesia.

\section{Method}

This research used survey research methodology and the most popular survey research design is the crosssectional survey design, that is the researcher collects data at one point in time and this design has advantage of measuring current practices or attitudes (Creswell, 2008). This survey design is considered appropriate for a preliminary study for this topic and the ease of data collection using e-form provided by Microsoft, is invaluable. The steps are as follow

1. Set the respondents criteria. The respondents are classified into two categories: those who just starting to work/novice teachers (0-2 year teaching English) and experienced teachers (>2 year teaching English) in order to see the differences and able to offer more suitable solutions or opportunities. They are teachers who work in two private schools in West Jakarta.

2. Construct the instrument. The researcher created an open-ended questionnaire which then validated by two lecturers from UPH English language education (ELE) department and piloted to 3 graduates from the same department who teach in primary level, also in private schools.

3. Distribute the open-ended questionnaire given to primary English teachers in Jakarta who work in schools under a private foundation with a consent letter. During data collection, only 7 participants were willing to participate in this research by filling out the openended questionnaire consisting of 7 main questions related to the aims of this research. With 1 male and 6 female teachers participating at the end of July 2020

4. Apply simple coding. It is to ease data analysis process by using the coding of PT1 to PT7 for those 7 participants.

5. Analyze the data. It is to group and eventually display the data using tables in order to answer the research questions.

\section{Results And Discussion}

This part displays data results in order to answer the research questions presented in the beginning. From the data collection and analysis, the common type of PD the respondents do during the pandemic are presented in the table below 
Table 1

Common PD Type

\begin{tabular}{|c|c|}
\hline More Frequent & Frequent \\
\hline Workshop/ & Having peer observations and coaching \\
\hline Conferences about & \\
\hline English teaching & \\
\hline Applying & Doing action research about teaching \\
\hline Teaching & English \\
\hline $\begin{array}{l}\text { Developing English } \\
\text { modules/handouts }\end{array}$ & Holding Teacher Support Groups (TSG) \\
\hline
\end{tabular}

From the table above, it can be concluded that primary English teachers have done various types usually done so far the world of English language teaching. More than 50\% answered joining workshop/conference about English teaching during CoVid19 pandemic and then having team teaching. There are new empowering cultures, when the educator around the world were sharing their expertise or experience of new learning situation. It is good to be the speaker or participant as they will gain new knowledge as the further anticipation for the learning experience in the pandemic situation. More and more webinars are available either in Zoom or in Youtube.

The researcher tried to compare novice teachers' preferences with more senior teachers and the results are as follow.

Table 2

PD Preferences

\begin{tabular}{cl}
\hline Novice Teachers & More Senior Teachers \\
\hline Only join & More collaborative such as team \\
workshops/conferences & teaching and holding TSG.
\end{tabular}

It can be well understood that novice teachers usually are still adapting to the new teaching environment so more personal PD ways are taken. Meanwhile, more senior teachers who are already getting along and experiencing collaboration with other primary teachers during many events in school, will be easier to apply collaboration as their PD way.

Regarding the challenges they faced during applying PD in table $1,50 \%$ of the respondents stated that internet connection problem is the challenge. This finding is interesting considering their location is in Jakarta, the capital city with higher access to internet and wi fi. If 
primary English teachers in Jakarta still experience technical issue like poor internet connection, how would primary teachers in remote areas or even in suburbans?

Other challenges including time management and the relevance of the PD content. One respondent stated as follow

It's just not contextual, different curriculum (PT5)

That kind of response signals the importance of relevance and significance in every PD opportunity. Every formal PD conducted by the school should employ needs analysis to ensure that the PD content will have high relevance and significance for the English primary teachers.
It can be well understood that novice teachers usually are still adapting to the new teaching environment so more personal PD ways are taken, but previous research by Rohmah (2018) shows that mentoring program which consists of monthly workshops, classroom observations and pre-and post-teaching conferences appears to have various benefits for the novice teachers involved. Therefore, the school can focus and encourage novice teachers more towards collaboration in the form of mentoring.

The following table summarizes their expectations from the school and also from the local government.

Table 3

Expectations for PD

\begin{tabular}{ll} 
The School & The Local Government \\
\hline A more applicable and a PD & More PD programs \\
about modifying onsite & \\
teaching into online teaching & \\
More PD held and clearer & Facilities support \\
instruction during PD & \\
Provide wifi & Clear instruction and system
\end{tabular}

It is shown in the table that the

There will be a lot of new ways how primary English teachers also expect that the school could provide applicable technology training and further anticipation strategy in delivering the learning material to the students in the home-based learning ( $\mathrm{HBL}$ ) setting. All the participants are doing $\mathrm{HBL}$ at the moment.

to communicate and collaborate effectively and productively. The further mapping and projection should be managed accordingly by looking the basic needs of the teacher to enhance the use of technology and how to present the lesson plan. A comprehensive needs analysis can be done not only for the primary teachers or even newcomers or 
novice teachers in the schools, but also to the students and parents in order to bring significant collaboration in the teaching and learning process.

Primary English teachers strongly expected that the local government could provide internet connectivity as the learning facility. The low internet connectivity was truly happening in the school area as the teacher could not connect with the students because of the internet availability and low connectivity. Teachers were challenged to think outside of the box in how they can equip the students to absorb the learning process. Besides that, the respondents from the questionnaire appreciate the effort from the local government in order to support the new learning mechanism which have been shared.

On the other hand, the PD design and experience that the teacher had mostly was about the theory of learning. They mentioned in the questionnaire that the school should provide enough applicable training in order to equip them as the front liner of education. They were trying their best to use the time effectively by joining any possible PD Webinar sessions to enrich their understanding and skills needed, especially to enhance the learning processes with the technology.

One teacher said he/she did not have any more passion to teach. The researcher predicts that in the new situation of learning caused by Covid-19, the internal well-being of teacher was very critical. The school leaders and government should be aware about how to maintain the training to the teacher about virtual learning scenario, but also the self-development (growth) of the teacher individually. It is tiring to face computer monitor or mobile phone for the day rather than interact individually with human. The inner well-being of the teacher holds important agenda as well as we prepare the technology advanced for teaching and learning.

Another point worth to be discussed is about technology in PD. Technology is created to make human's life simple. Somehow, the advancement of technology could make a complicated way of living as well. Baby boomer generation teachers should find a way to adapt of using the technology in their classroom because this experience will be a new way for them to deal with it. This situation will be smooth if there is a space to collaborate between the millennials generation teachers to fit the technology needs. Therefore, PD in the form of TSG, team teaching, and even peer observation will be very helpful for them in this pandemic situation. The schools might also consider the way to socialize the use of technology and online platform that has been decided and used in the school. Good socialization affects the teachers' perception and response.

\section{Conclusion}

There are three conclusions based on the data analysis as follow

1.The primary English teachers in two private schools in West Jakarta have done various types of PD and the most common types of PD done by them are webinars sessions and applying team teaching. 
2. The challenges they face can be categorized into two: internal and external. The internal challenge is related to time management that also affects the teacher's well-being as they need to manage their responsibilities as a parent, husband or housewife, church members, and administrative duties. The external factor that occur is the internet connectivity in the learner's area especially for those in the remote places. The local government should strive to support accordingly towards the learner's needs.

3. Primary English teachers expect three things from the school where they teach: (1). Support for their learning strategy by enhancing the technology to make efficient and productive learning work; (2). The clarity and intentionality of PD agenda in which guiding the teacher step by step with the technology advancement; (3). Internet connectivity which supports the teachers to deliver the English lesson well.

Meanwhile, their expectations for the local government are mainly provided some PD programs, technology facility advancement support, and clear instruction and system. These things will be meaningful to support the primary teachers who will accommodate new strategic plan for English learning.

It is recommended for the local government collaborate with the schools to ensure and improve the primary English teachers through qualified PD programs/ways. Furthermore, there is an urgency to begin with improving infrastructure that supports online learning or even PD done online.

\section{References}

Brown, D. H., \& Abeywicrama, P. (2004). Language assessment: Principles and classroom practices. New York: Pearson.

Creswell, J. (2008). Educational research: planning, conducting, and evaluating quantitative and qualitative research. New Jersey: Pearson Education.

Hargreaves, A., Liberman, A., Fullan, M., \& Hopkins, D. (Eds. . (Eds.). (1998). International handbook of educational change. Boston: Kluwer Academic.

Harmer, J. (2001a). How to teach English: An introduction to the practice of English language teaching. Harlow, United Kingdom: Pearson Education Limited.

Harmer, J. (2001b). The Practice of English language teaching. Harlow, United Kingdom: Pearson Education Limited.

Richards, J. C., \& Farrell, T. S. (2005). Professional development for language teachers: Strategies for teacher learning. United States of America: Cambridge 
University Press.

Rohmah, Z. (2018). Enhancing English Teachers' Professional Development: Portraying A Mentoring Program. TEFLIN Journal. Retrieved from http://journal.teflin.org/index.php/journal/article/view/582/294 on December 4, 2020

9 | Primary English Teachers Professional Development During Covid19 Pandemic....... 